\title{
Atrial Natriuretic Peptide: A Regulator of Transvascular Fluid Transport in Dialysis?
}

\author{
R. Zietse \\ Department of Internal Medicine, Erasmus Medical Center Rotterdam, Rotterdam, The Netherlands
}

The determination of dry weight in dialysis has always been elusive, and to this day remains the Holy Grail in dialysis treatment. Various techniques have been propagated to give an estimation of dry weight, including bioimpedance, blood volume measurement, measurement of inferior caval vein diameter and the concentration of various natriuretic peptides.

In the event of circulatory underfilling, due to excessive ultrafiltration, symptomatic hypotension may ensue. The maintenance of plasma volume is determined by both ultrafiltration rates and the rate of vascular refilling from the interstitium. Schneditz et al. [1] have attempted to determine the capillary filtration coefficient (Lp), that describes net water flow $\left(J_{\mathrm{v}}\right)$ in Starling's equation. Several other authors have also used these computations, based on an open two-compartment model, to study the contribution of (changes in) Lp on blood volume preservation during dialysis [2, 3].

Changes in blood volume, estimated by changes in the concentration of circulating blood components such a hematocrit, may be even greater than apparent from relative blood volume measurements. As hematocrit is not homogeneously distributed throughout the body, Mitra et al. [4] compared relative blood volume measurements to the gold standard measurement of plasma volume using indocyanine green dilution techniques. They demonstrated that the difference between systemic and whole-body hematocrit (F-cell ratio) increases progressively during dialysis, indicating a redistribution of the red cell mass.
Moreover, a wide variation in the course of relative blood volume during dialysis was previously described by Krepel et al. [5]. In this paper, no statistical relationship could be found between changes in relative blood volume and either inferior caval vein diameter (ICVD) or blood pressure, indicating that the initiation of hypotension may result from defective cardiovascular defense mechanisms.

Natriuretic peptides are released by the heart in response to derangements in blood pressure and extracellular volume. Wallin et al. [6] described the high correlation between plasma ANP levels and cardiac output in patients on dialysis. However, they also observed a discrepancy between the reduction in cardiac output and central blood volume during dialysis.

In this journal, Yashiro et al. [7] describe the relationship between atrial natriuretic peptide (ANP), ICVD and Lp. They demonstrate a highly significant relationship between ANP levels and Lp values. The observed relationship between plasma ANP levels and Lp raises the question whether the increased ANP levels may have been instrumental in the increased hydraulic permeability of the capillaries. Their approach corrects for a changing plasma protein concentration, but the transcapillary oncotic gradient may decrease due to increased transcapillary escape of protein [8]. Moreover, changes in the transcapillary hydrostatic pressure gradient cannot be excluded as ICVD also correlated with Lp.

\section{KARGER \\ Fax +4161306 1234 E-Mail karger@karger.ch} www.karger.com
(C) 2005 S. Karger AG, Basel 0253-5068/05/0236-0429\$22.00/0

Accessible online at:

www.karger.com/bpu
Robert Zietse, MD

Department of Internal Medicine

Erasmus Medical Center Rotterdam

NL-3000 CA Rotterdam (The Netherlands)

Tel. +31 10 4639222, Fax +31 10 4635756, E-Mail r.zietse@erasmusmc.nl 
In addition to its effect on diuresis and natriuresis, ANP has been shown to directly influence the distribution of volume between the intravascular and interstitial fluid compartments. As early as 1986, Flückiger [9] demonstrated that infusion of ANP reduces plasma volume in nephrectomized rats. This reduction in plasma volume, obviously by a mechanism independent of urinary output, has been poorly understood. It has been hypothesized that these changes were due to either direct regulation of vascular tone by ANP, or by indirect regulation through angiotensin II or the sympathetic nervous system. For this reason it was suggested to use natriuretic compounds for the treatment of volume overload in acute renal failure, as is currently widely practiced in acute heart failure [10].

A recent publication of the elegant studies by Sabrane et al. [11] appears to shed some light on the pathophysiological mechanism of the extrarenal effects of ANP. In an endothelium-restricted deletion of the guanylyl cyclase-A (GC-A) gene, also known as natriuretic peptide receptor 1 , they observed an increase in plasma volume by $11-13 \%$, independent of sodium balance. These knock- out mice developed left ventricular hypertrophy, secondary to a chronically increased preload. Therefore, GC-Amediated changes in endothelial permeability appeared to be of critical importance in the hypovolemic actions of ANP.

As the maintenance of a physiologically desirable plasma volume is the interplay between the capillary Starling forces, it is of importance for ANP to influence both sodium excretion and transcapillary fluid exchange. If the effect of ANP were exclusively on sodium excretion, the resulting increase in plasma oncotic pressure would result in transport from the interstitial fluid volume to the circulation. Therefore, the extrarenal actions of ANP are essential for the peptide to preferentially regulate plasma volume.

Due to its design, the study of Yashiro et al. [7] cannot answer the question on the physiological importance of the extrarenal actions of ANP in dialysis patients. It does however raise an important question that merits further investigation. It remains to be seen whether the determination of $\mathrm{Lp}$ will improve patient care in the hemodialysis population.

\section{References}

1 Schneditz D, Roob J, Oswald M, Pogglitsch H, Moser M, Kenner T, Binswanger U: Nature and rate of vascular refilling during hemodialysis and ultrafiltration. Kidney Int 1992;42: 1425-1433.

2 Yashiro M, Hamada Y, Matsushima H, Muso E: Estimation of filtration coefficients and circulating plasma volume by continuously monitoring hematocrit during hemodialysis. Blood Purif 2002;20:569-576.

3 Ishibe S, Peixoto AJ: Methods of assessment of volume status and intercompartmental fluid shifts in hemodialysis patients: implications in clinical practice. Semin Dial 2004; 1:37-43.
4 Mitra S, Chamney P, Greenwood R, Farrington $\mathrm{K}$ : The relationship between systemic and whole-body hematocrit is not constant during ultrafiltration on hemodialysis. J Am Soc Nephrol 2004;15:463-469.

5 Krepel HP, Nette RW, Akçahüseyin E, Weimar W, Zietse R: Variability of relative blood volume during haemodialysis. Nephrol Dial Transplant 2000;15:673-679.

6 Wallin CJB, Rossi P, Jacobson SH, Leksell LG: Central blood volume, atrial natriuretic peptide and intermittent hemodialysis. Scand J Urol Nephrol 2204;38:78-84.

7 Yashiro M, Watanabe H, Tomita M, Yamadori N, Muso E: Relationship between filtration coefficients of microvasculature and levels of atrial natriuretic peptide or echocardiographic measurements. Blood Purification 2005;23:431-439.
8 Zietse R, Derkx FH, Weimar W, Schalekamp MA: Effect of atrial natriuretic peptide on renal and vascular permeability in diabetes mellitus. J Am Soc Nephrol 1995;5:2057-2066.

9 Flückiger JP: Effect of atriopeptin III on hematocrit and volemia of nephrectomized rats. Am J Physiol 1986;251:880-883.

10 Joffy S, Rosner MH: Natriuretic peptides in ESRD. Am J Kidney Dis 2005;46:1-10.

11 Sabrane K, Kruse MN, Fabritz L, Zetsche B, Mitko D, Skryabin BV, Zwiener M, Baba HA, Yanagisawa M, Kuhn M: Vascular endothelium is critically involved in the hypotensive and hypovolemic actions of atrial natriuretic peptide. J Clin Invest 2005; 115:1666-1674. 